\title{
Snowpack Chemistry at Selected Sites in Colorado and New Mexico during Winter 1999-2000
}

By George P. Ingersoll

U.S. GEOLOGICAL SURVEY

Open-File Report 00-394

Prepared in cooperation with the NATIONAL PARK SERVICE and the

U.S. ENVIRONMENTAL PROTECTION AGENCY 


\title{
U.S. DEPARTMENT OF THE INTERIOR BRUCE BABBITT, Secretary
}

\author{
U.S. GEOLOGICAL SURVEY
}

Charles G. Groat, Director

The use of firm, trade, and brand names in this report is for identification purposes only and does not constitute endorsement by the U.S. Geological Survey.

For additional information write to:

District Chief

U.S. Geological Survey

Box 25046, Mail Stop 415

Denver Federal Center

Denver, CO 80225-0046
Copies of this report can be purchased from:

U.S. Geological Survey

Information Services

Box 25286

Federal Center

Denver, CO 80225 


\section{CONTENTS}

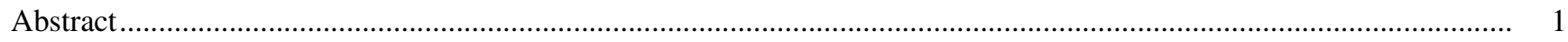

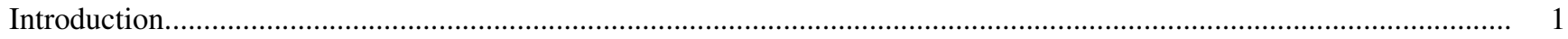

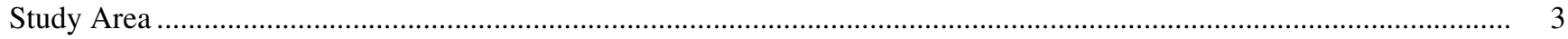

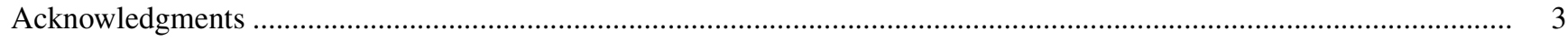

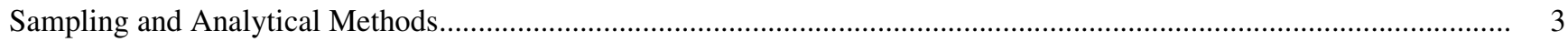

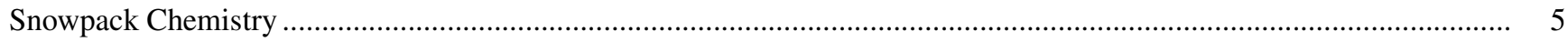

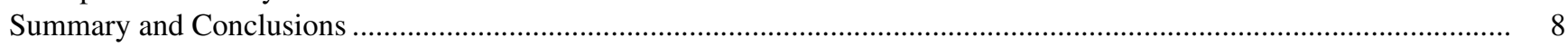

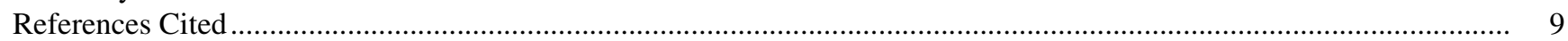

\section{FIGURES}

1. Map showing snow-sampling sites and reservoirs in the study area and power plants in the Four Corners area ....... 2

2-4. Graphs showing

2. Selected major-ion concentrations at snow-sampling sites................................................................ 7

3. Selected trace-element concentrations at snow-sampling sites............................................................... 7

4. $\delta^{34} \mathrm{~S}$ sulfur-isotope compositions at snow-sampling sites.................................................................. 7

\section{TABLES}

1. Selected chemical concentrations for snowpack sampling sites .................................................................

2. Selected average chemical concentrations for 1993-99 snowpacks at sampling sites near the Lizard Head Pass and Culebra sites.

3. Selected chemical concentrations in coal used for power production during winter 1999-2000

near Four Corners area 


\title{
Snowpack Chemistry at Selected Sites in Colorado and New Mexico during Winter 1999-2000
}

\author{
By George P. Ingersoll
}

\section{Abstract}

Snowpacks at two high-elevation (> 3,000 m) sampling sites near McPhee and Sanchez Reservoirs in southern Colorado were selected to collect representative samples of atmospheric deposition to the surrounding watersheds during winter 1999-2000. In February 2000, annual snowpacks at two sites were sampled to determine concentrations of nitrate and sulfate; concentrations of the trace elements arsenic, mercury, and selenium; and the sulfur isotope ratios that result from atmospheric deposition to the area. Snowpack chemistry data at the two sites sampled in 1999-2000 are compared to 1993-99 averages at 10 other snow-sampling sites in Colorado and New Mexico that generally are downwind of the Four Corners area of the southwestern United States. Although concentrations of ammonium and nitrate in the 1999-2000 snowpacks were fairly typical compared to averages established at nearby sites in southern Colorado and northern New Mexico, chloride and sulfate concentrations were below the 1993-99 average, while arsenic, mercury, and selenium in snow were much below the 1993-99 average. However, very similar sulfur-isotope ratios (that are not a function of precipitation amounts) deposited in snowpacks at the nearby sites indicate the snowpack chemistries at the new sampling locations near McPhee and Sanchez reservoirs were affected by similar sources of sulfate.

Representative samples of coal burned during the 1999-2000 snowfall season at three power plants near Four Corners also were analyzed for sulfur content and trace elements. Results from separate, independent laboratories show similar concentrations and provide an initial baseline that will be used for general comparisons of coal chemistry to snowpack chemistry.

\section{INTRODUCTION}

The annual snowpack represents most of the yearly precipitation that falls in high-elevation basins of the Rocky Mountains, and is a good indicator of precipitation chemistry in mountainous areas because the snowpack collects chemical deposition throughout the winter. Because snowmelt supplies most of the water in mountain lakes, streams, and wetlands in the area, accumulation of atmospheric pollutants in the snowpack may adversely affect the hydrochemistry of mountainous watersheds and may threaten ecosystem health (Cogbill and Likens, 1974). Alpine and subalpine environments are sensitive to deposition of acids associated with fossil-fuel combustion because of the limited capacity of soils and dilute waters to neutralize acidic inputs. Acidic deposition in this setting may be detrimental to plant and wildlife populations (Corn and others, 1989). Numerous emissions that may affect air and water quality in southern Colorado are released along the Denver-Colorado Springs urban corridor and in western Colorado from agricultural, industrial, residential, and urban sources. Other work has demonstrated substantial emissions from sources in western and eastern Colorado (Turk and Campbell, 1987; Denning and others, 1991; Ingersoll, 1995; Williams and others, 1996; Turk and Campbell, 1997, Williams and others, 1998). 
The U.S. Geological Survey (USGS) has been monitoring snowpack chemistry at more than 50 locations throughout the Rocky Mountain region annually since 1993. Methods and protocols to detect a variety of major ions, organics, trace elements, and isotopes in annual snowpacks have been developed to identify local and regional emissions sources (Campbell and others, 1991; Turk and others, 1992; Ingersoll, 1995, 1999; Mast and others, in press). Several years of analyzing snowpack chemistry from the network of sampling sites throughout the Rocky Mountain region provide the basis for determination of typical concentrations of many major ions and trace elements, and ratios of sulfur isotopes in snowpacks. This large network, which extends from northern New Mexico to northern Montana, has enabled the USGS to identify areas of low, moderate, and high concentrations of acidic pollutants within the region and to locate probable local and regional sources of atmospheric deposition to snowpacks.
Current monitoring efforts are insufficient to make interpretations of probable sources of chemical deposition in southern Colorado. Information about snowpack chemistry, in particular concentrations of acid precursors such as nitrate and sulfate and of trace elements, is needed in support of ongoing U.S. Environmental Protection Agency (USEPA) water-quality investigations at McPhee and Sanchez Reservoirs. To address these needs, the USGS, in cooperation with the National Park Service and the USEPA, conducted a study of snowpack chemistry in southern Colorado and northern New Mexico. Two new snowpacksampling sites were added to the USGS network of sampling sites in the Rocky Mountain region during winter 1999-2000. One site was selected in the watershed of McPhee Reservoir (Lizard Head Pass), and one site was selected near Sanchez Reservoir (Culebra) (fig 1).

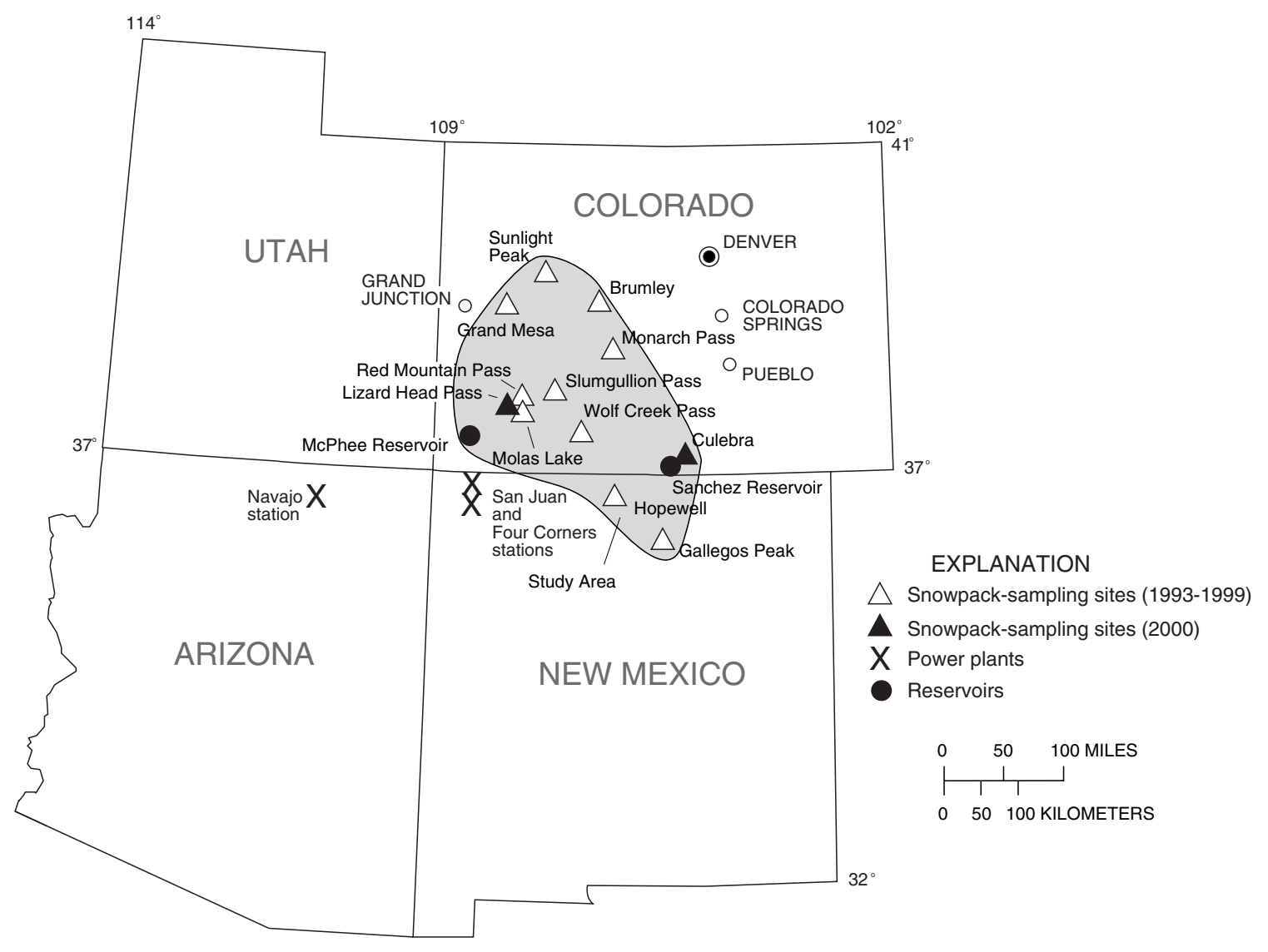

Figure 1. Snow-sampling sites and reservoirs in the study area and power plants in the Four Corners area. 
The purpose of this report is to describe initial chemical data as a first step toward determination of sources and concentrations of major ions and trace elements present in snowpack that may potentially affect water quality in McPhee and Sanchez Reservoirs. Specifically, results presented in this report establish a baseline of chemical concentrations atmospherically-deposited in snowpacks, and provide comparisons of those concentrations to average concentrations of other snowpacks in southern Colorado and northern New Mexico. Because coal-fired power plants are some of the largest point sources of emissions in the Four Corners area (U.S. Environmental Protection Agency, 2000a), chemical levels found in coals burned at selected power plants during the winter of 1999-2000 (December and January) are presented.

\section{STUDY AREA}

The study area includes parts of Colorado and New Mexico near the Four Corners area of the southwestern United States. Two snow-sampling sites were selected at high-elevations (> 3,000 m) in the Rocky Mountains of southern Colorado near Sanchez and McPhee Reservoirs (fig. 1). Sampling sites were collocated near the Culebra \#2 and Lizard Head Pass snow telemetry (Snotel) sites where annual snowpacks persist without significant melting during winter (for Snotel information, access http://www.wcc.nrcs.usda.gov/water). Both snowsampling sites are in remote areas where little local activity occurs that might contaminate the annual snowpacks. Tundra grasses, aspen, and conifers dominate the vegetation. Snowfall accumulates from October to late March or April and represents more than half of the yearly precipitation at the study sites based on 30-year (1961-90) averages at the nearby Snotel sites (Gillespie, 1991).

Three coal-fired power plants operate in the Four Corners area (Four Corners, Navajo, and San Juan stations, fig. 1). These large point-sources of emissions of sulfur dioxide (U.S. Environmental Protection Agency, 2000a) and other chemicals are of interest in this study because of proximity to the snowpack sampling sites at Lizard Head Pass and Culebra \#2 Snotel sites. Storms traversing Colorado more frequently originate in the west than in the east, thus air masses may travel through the Four Corners area before reaching sampling sites in the study area.

\section{ACKNOWLEDGMENTS}

Cooperation from Kathy Tonnessen of the National Park Service, Air Resources Division, and Kathy Hernandez of the USEPA, Region VIII, made this study possible. Assistance from Larry Kawanabe of the USDA Natural Resources Conservation Service for sampling site information and access was appreciated. Thanks are in order to Don Campbell, David Clow, Jaime Giesen, Ben Glass, Heather Handran, Nan Ingersoll, Dawn Jewell, Alisa Mast, Leora Nanus, and Andres Torizzo of the USGS for logistical coordination, field and laboratory work, and quality assurance. The author also wishes to thank Ron Antweiler, Terry Plowman, David Roth, and Howard Taylor of the USGS for analytical work and assistance with sampling design. The two technical reviewers Ron Antweiler and Janet Heiny of the USGS greatly added to the quality of this report. Thanks also are due to Carol Anderson, Ed Swibas, Sharon Clendening, Alene Brogan, Joy Monson, Margo VanAlstine of the USGS, and the rest of the Colorado District Publications Section responsible for producing the final document.

\section{SAMPLING AND ANALYTICAL METHODS}

Sites were selected in small clearings below tree line in areas with uniform snow cover and limited local anthropogenic activity and were located at least $500 \mathrm{~m}$ from plowed roadways to minimize contamination from vehicular traffic. Several depth measurements were taken near potential sampling sites to assess the variance in the thickness of the snowcover and to allow selection of specific snowpit sites where snow depth is more representative of mean depths in the area. Scoured or drifted snowscapes were avoided because such areas would not be representative of the annual snowpack that contained layers from all snowfall events.

Below-average snowpack depths during February 2000 indicated the thin snowpacks might melt earlier than usual, especially because warming temperatures are not uncommon in late winter in southern Colorado. Thus, snow samples were 
collected 4 to 6 weeks before the beginning of spring melt was expected to preserve the chemical record of the snowpack. Early in the annual snowmelt process, a concentrated elution forms as ions are leached from the snowpack (Campbell and others, 1995; Williams and others, 1996), and as a result, the chemistry of the snowpack changes. By sampling several weeks before melt begins, most annual snowfall may be collected in a single sample, and annual chemical deposition remains intact. Timing sample collection this far in advance of the typical beginning of melt from the snowpack increased the likelihood of sampling about 80 to 90 percent of total annual snowfall and provides a good indicator of atmospheric deposition for a substantial part of the year.

Full-strata snow samples, replicates, and field blanks were collected at the Lizard Head Pass site on February 26, 2000, and at the Culebra site on February 27, 2000. Snowpits were prepared with a smooth, freshly cut, vertical face extending from the ground surface upward throughout the entire depth of the snowpack. Before snow samples were collected, full-snowpack temperature profiles were recorded at 10- or 20-cm intervals; snow-crystal size, type, and hardness of all homogeneous strata were measured; and further observations of ice layers, evidence of melt, saturated wet snow, and soil moisture beneath the snowpack were recorded to verify that snowmelt elution had not yet begun.

Because of the extremely dilute chemistry of snow at sampling sites, snow samples were carefully collected to prevent contamination. The bottom $10 \mathrm{~cm}$ of the snowpack was not sampled to avoid inclusion of forest litter and soil in the samples. The top $5 \mathrm{~cm}$ of snowpack was discarded to exclude snow contaminated by activities resulting from transport to and preparation of the snowpit. Tyvek suits and latex laboratory gloves were worn by field personnel, and clean plastic shovels and scoops were used to collect a vertical column of snow representative of the entire snowpack. After collection of snow samples, field and equipment blanks were taken for analyses of majorion- and trace-element contamination at each snowpit site by pouring high-purity $(18 \mathrm{megohm}-\mathrm{cm})$ deionized water over sampling tools and into a Teflon sample bag. Workers in the snowpits took precautions to avoid contamination by foreign substances such as animal waste, forest litter, perspiration, or soil when filling sample containers. The snow columns were cut and samples placed in 8-L Teflon bags and 60-L plastic carboys that were prerinsed in high-purity deionized water. These containers were sealed to prevent contamination and transported to a USGS research laboratory in Boulder, Colorado, for analysis. The 8-L samples were kept frozen to prevent chemical reactivity prior to laboratory analysis for major ions, nutrients, and trace elements. The 60-L samples collected for analyses of stable sulfur isotopic ratios were allowed to attain room temperature from the time of collection until the date of analysis.

Snow samples collected in Teflon bags for major ions, nutrients, and trace-element analyses were melted prior to laboratory processing according to methods described by Ingersoll (1995). Samples for major cations and trace elements were filtered through $0.45-\mu \mathrm{m}$ polycarbonate filters into acid-washed bottles and then acidified with double-distilled concentrated nitric acid. Samples for anion and nutrient analyses were filtered though $0.45-\mu \mathrm{m}$ membrane filters into prerinsed bottles. An unfiltered sample was collected for alkalinity and $\mathrm{pH}$ determination. Laboratoryprocess- and Teflon-sample-bag blanks were analyzed for quality control.

Major cations were analyzed by inductively coupled plasma atomic emission spectroscopy (Garbarino and Taylor, 1979), and major anions were analyzed by ion chromatography (Brinton and others, 1996). Nutrients analyses were done using techniques from Antweiler and others (1993), and trace-element analyses used methods from Garbarino and Taylor (1995). Snow samples for sulfur isotope analyses were acidified to $\mathrm{pH} 4.5$ then pumped through an ionexchange column to concentrate the sample. Sulfate was eluted from the column and precipitated as barium sulfate which was analyzed by mass spectrometry as described by Mast and others (in press). Units of isotope ratios are expressed as per mil relative to the Canyon Diablo Troilite standard (Faure, 1986) and have a precision of \pm 0.2 per mil.

Coal samples from three power plants in the area that represent fuel burned during winter 1999-2000 were collected and analyzed for mercury and sulfur content by personnel at the individual power plants using American Society for Testing and Materials (ASTM) methods as part of the Electric Utility Steam Generating Units Hazardous Air Pollutant Emission Study (U.S. Environmental Protection Agency, 2000b). In addition, coal samples from the same period (December 1999-January 2000) were shipped in sealed containers to USGS laboratories in 
Boulder, Colorado, for independent analyses. Total digestions for determination of mass of arsenic, mercury, selenium, and sulfur were conducted on the solid coal samples after disaggregation at the USGS laboratory in Boulder, Colorado.

\section{SNOWPACK CHEMISTRY}

By March 1, 2000, water contents of the annual snowpacks were still much below average, and when snow samples were collected February 26 and 27, 2000, snowpack water contents were 72 and 77 percent of the 30-year average at the collocated Snotel sites Culebra \#2 and Lizard Head Pass, respectively (Gillespie, 2000). Water contents at the collocated Snotel sites at the time of sampling were $19 \mathrm{~cm}$ at Culebra \#2 and $26 \mathrm{~cm}$ at Lizard Head Pass; snow depths at the two sampling pits were $70 \mathrm{~cm}$ (selected from a range of 60 to $80 \mathrm{~cm}$ ) at Culebra, and $128 \mathrm{~cm}$ (from a range of 120 to $130 \mathrm{~cm}$ ) at Lizard Head Pass. Temperatures of all snowpack layers ranged from -1.0 to $-6.0^{\circ} \mathrm{C}$; no evidence of melt was observed.

Snowpack chemistry for selected major ions, trace elements, and the sulfur-isotope ratio are listed in table 1 for the Lizard Head Pass and Culebra sites. Replicate snow-sample results show close agreement at both snow-sampling sites. Field, sample-bag, and laboratory blanks indicate contamination was limited. At both sites, the sulfur isotopes ratios $\left(\delta^{34} S\right)$ and concentrations of chloride $\left(\mathrm{Cl}^{-}\right)$, nitrate $\left(\mathrm{NO}_{3}{ }^{-}\right)$, and sulfate $\left(\mathrm{SO}_{4}{ }^{2-}\right)$ were similar; trace-element concentrations of arsenic (As), mercury ( $\mathrm{Hg}$ ), and selenium (Se) were nearly identical.

Comparison of the 1999-2000 snowpack chemistry at the Culebra and Lizard Head Pass sites to the 1993-99 average concentrations in snowpacks at 10 nearby sites shows interesting patterns (tables 1 and 2; figs. 2, 3, and 4). Ammonium and nitrate concentrations and sulfur-isotope ratios were close to 7-year averages (1993-99) at nearby sites. Chloride and sulfate concentrations were below average while arsenic, mercury, and selenium were much below average. The ranges of concentrations in snow at the two sites sampled in February 2000 for ammonium ( 2.3 to $4.3 \mu \mathrm{eq} / \mathrm{L}$ ) and nitrate $(9.2$ to $11.1 \mu \mathrm{eq} / \mathrm{L})$ are within ranges of 1993-99 concentrations of ammo$\operatorname{nium}(2.2$ to $4.9 \mu \mathrm{eq} / \mathrm{L})$ and nitrate $(6.9$ to $12.0 \mu \mathrm{eq} / \mathrm{L})$ at nearby snow-sampling sites. However, sulfate (4.2 to $5.6 \mu \mathrm{eq} / \mathrm{L})$ and chloride $(<0.6$ to $0.9 \mu \mathrm{eq} / \mathrm{L})$ concentrations at the two sites were at or below the low end of the range of 1993-99 average concentrations for sulfate (4.9 to $10.1 \mu \mathrm{eq} / \mathrm{L})$ and chloride (0.9 to $1.8 \mu \mathrm{eq} / \mathrm{L})$. Further, ranges of concentrations of arsenic $(<0.01$ to $0.02 \mu \mathrm{g} / \mathrm{L})$, mercury $(<0.0003$ to $0.0004 \mu \mathrm{g} / \mathrm{L})$, and selenium $(<0.05$ to $0.07 \mu \mathrm{g} / \mathrm{L})$ were noticeably lower than the 1993-99 average concentrations in nearby snowpacks of arsenic ( 0.05 to $0.14 \mu \mathrm{g} / \mathrm{L})$, mercury $(0.0007$ to $0.0010 \mu \mathrm{g} / \mathrm{L})$, and selenium $(0.15$ to $0.36 \mu \mathrm{g} / \mathrm{L})$.

Table 1. Selected chemical concentrations for snowpack sampling sites

[ $\mu$ eq/L, microequivalents per liter; $\mu \mathrm{g} / \mathrm{L}$, micrograms per liter; $\%$ oo, per mil; na, not analyzed]

\begin{tabular}{|c|c|c|c|c|c|c|c|c|c|}
\hline Site Name & $\begin{array}{c}\text { Sample } \\
\text { Date }\end{array}$ & $\begin{array}{c}\text { Ammo- } \\
\text { nium } \\
(\mu \mathrm{eq} / \mathrm{L})\end{array}$ & $\begin{array}{c}\text { Chlo- } \\
\text { ride } \\
\text { ( } \mu \text { eq/L) }\end{array}$ & $\begin{array}{l}\text { Nitrate } \\
(\mu e q / L)\end{array}$ & $\begin{array}{l}\text { Sulfate } \\
\text { ( } \mu \text { eq/L) }\end{array}$ & $\begin{array}{c}\text { Arsenic } \\
(\mu \mathrm{g} / \mathrm{L})\end{array}$ & $\begin{array}{c}\text { Mercury } \\
(\mu \mathrm{g} / \mathrm{L})\end{array}$ & $\begin{array}{l}\text { Sele- } \\
\text { nium } \\
(\mu \mathrm{g} / \mathrm{L})\end{array}$ & $\begin{array}{l}\delta^{34} s \\
(\%)\end{array}$ \\
\hline Lizard Head Pass & $2 / 26 / 00$ & 2.3 & 0.9 & 11.1 & 4.2 & 0.02 & $<0.0003$ & $<0.05$ & 4.8 \\
\hline $\begin{array}{l}\text { Lizard Head Pass Repli- } \\
\text { cate }\end{array}$ & $2 / 26 / 00$ & 2.7 & 0.8 & 9.4 & 4.5 & 0.02 & $<0.0003$ & 0.05 & 4.7 \\
\hline $\begin{array}{l}\text { Lizard Head Pass Field } \\
\text { Blank }\end{array}$ & $2 / 26 / 00$ & 0.4 & $<0.6$ & 0.6 & $<1.0$ & $<0.01$ & $<0.0003$ & $<0.05$ & na \\
\hline Laboratory Blank & $2 / 29 / 00$ & 0.4 & $<0.6$ & 2.2 & $<1.0$ & $<0.01$ & $<0.0003$ & $<0.05$ & na \\
\hline Sample Bag Blank & $2 / 29 / 00$ & 0.4 & $<0.6$ & 0.6 & $<1.0$ & $<0.01$ & $<0.0003$ & $<0.05$ & na \\
\hline Culebra & $2 / 27 / 00$ & 4.3 & 0.7 & 9.2 & 5.6 & 0.02 & 0.0004 & 0.07 & 5.0 \\
\hline Culebra Replicate & $2 / 27 / 00$ & 3.9 & 0.8 & 9.0 & 5.7 & 0.02 & $<0.0003$ & $<0.05$ & 5.1 \\
\hline Culebra Field Blank & $2 / 27 / 00$ & 0.4 & $<0.6$ & 0.6 & $<1.0$ & $<0.01$ & $<0.0003$ & $<0.05$ & na \\
\hline Laboratory Blank & $2 / 26 / 00$ & 0.4 & $<0.6$ & 0.7 & $<1.0$ & $<0.01$ & $<0.0003$ & $<0.05$ & na \\
\hline
\end{tabular}


Table 2. Selected average chemical concentrations for 1993-99 snowpacks at sampling sites near the Lizard Head Pass and Culebra sites

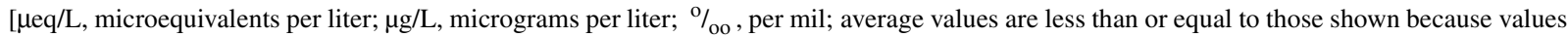
reported at or below detection limits were included (e.g., values such as " $<0.02 "$ in averages as 0.02 )]

\begin{tabular}{lcccccccc}
\hline \multicolumn{1}{c}{ Site Name } & $\begin{array}{c}\text { Ammonium } \\
(\mu \mathbf{e q} / \mathbf{L})\end{array}$ & $\begin{array}{c}\text { Chlo- } \\
\text { ride } \\
(\mu \mathbf{e q} / \mathbf{L})\end{array}$ & $\begin{array}{c}\text { Nitrate } \\
(\mu \mathbf{e q} / \mathbf{L})\end{array}$ & $\begin{array}{c}\text { Sulfate } \\
(\mu \mathbf{e q} / \mathbf{L})\end{array}$ & $\begin{array}{c}\text { Arsenic } \\
(\boldsymbol{\mu} \mathbf{g} / \mathbf{L})\end{array}$ & $\begin{array}{c}\text { Mercury } \\
(\mu \mathbf{g} / \mathbf{L})\end{array}$ & $\begin{array}{c}\text { Sele- } \\
\mathbf{n i u m} \\
(\boldsymbol{\mu} \mathbf{g} / \mathbf{L})\end{array}$ & $\begin{array}{c}\delta^{\mathbf{3 4}} \mathbf{S} \\
(\boldsymbol{\%} / \mathbf{o o})\end{array}$ \\
\hline Brumley & 2.6 & 0.9 & 7.8 & 4.9 & 0.05 & 0.0008 & 0.19 & 5.3 \\
Gallegos Peak & 4.8 & 1.3 & 9.5 & 9.8 & 0.14 & 0.0007 & 0.36 & 4.3 \\
Grand Mesa & 4.9 & 1.3 & 9.4 & 9.6 & 0.08 & 0.0009 & 0.22 & 4.6 \\
Hopewell & 4.6 & 1.4 & 12.0 & 10.1 & 0.14 & 0.0008 & 0.36 & 4.0 \\
Molas Lake & 2.9 & 1.4 & 8.2 & 6.2 & 0.08 & 0.0008 & 0.15 & 3.9 \\
Monarch Pass & 3.4 & 1.2 & 9.1 & 6.4 & 0.06 & 0.0008 & 0.19 & 5.3 \\
Red Mountain Pass & 2.7 & 1.5 & 9.0 & 6.6 & 0.10 & 0.0008 & 0.30 & 4.5 \\
Slumgullion Pass & 2.2 & 1.7 & 6.9 & 5.8 & 0.08 & 0.0010 & 0.23 & 4.3 \\
Sunlight Peak & 4.4 & 1.0 & 9.1 & 7.0 & 0.06 & 0.0008 & 0.22 & 5.3 \\
Wolf Creek Pass & 4.0 & 1.8 & 9.7 & 8.6 & 0.14 & 0.0007 & 0.36 & 4.3 \\
\hline
\end{tabular}

Earlier investigations of bulk atmospheric deposition to the study area during $1982-83$ found higher concentrations of nitrate (18 to $30 \mu \mathrm{eq} / \mathrm{L})$ and sulfate (41 to $63 \mu \mathrm{eq} / \mathrm{L}$ ) in annually-composited bulk samples in southern Colorado (Lewis and others, 1984) compared to the snowpack collected in 2000 at Lizard Head Pass and Culebra. The samples with higher concentrations might include summer precipitation and reflect the time period before reductions of emissions of nitrogen- and sulfur dioxide were realized during the mid-1990s (National Acid Precipitation Assessment Program, 1998). Other more recent work (1998) in the study area by the National Atmospheric Deposition Program (National Atmospheric Deposition Program, 2000) has detected nitrate and sulfate concentrations from precipitation at sites in southern Colorado similar to those detected in the snowpacks sampled at the Lizard Head Pass and Culebra sites during February 2000.

The lower concentrations of sulfate, chloride, and the trace elements detected in the snowpacks at the Lizard Head Pass and Culebra sites compared to the 10 nearby sites could be due to below-average snowfall. As more data become available for the 1999-2000 chemistry of other snowpacks at the nearby sites, this possibility may be further validated. Monitoring snowpack chemistry in the study area should be continued to better understand the effects of above- or below-average precipitation years on atmospheric deposition.
However, ammonium and nitrate concentrations also should be low if precipitation was the limiting factor. One possible explanation is that concentrations of nitrogen dioxide in atmospheric emissions exceeded those of sulfur dioxide during the snowfall season enabling greater concentrations of the nitrogen compounds ammonium and nitrate to be scavenged from the atmosphere during the limited precipitation events. In addition to the large sulfur-dioxide sources at the three power plants near the Four Corners area, numerous point sources of more than 100 tons of nitrogen dioxide per day were present in the area (U.S. Environmental Protection Agency, 2000a).

Despite uncertainties as to the reasons for elevated concentrations of nitrogen-bearing chemical constituents in comparison to the lower-than average concentrations of sulfate, arsenic, mercury, and selenium in a lower-than average snowfall season, the sulfur-isotope ratio provides a tracer that is not as dependent on precipitation amounts as are concentrations of other chemical constituents in the study. The effect of precipitation amounts on values of isotopic ratios is insignificant (as long as there is enough sample to perform the isotopic analyses). Thus, geographic patterns of deposition of sulfur compounds derived from particular sources (Mast and others, in press) will be relatively unaffected by below- or above-average precipitation amounts. Therefore, the sulfur-isotope ratios from the Lizard Head Pass and Culebra sites are meaningful despite the below- 

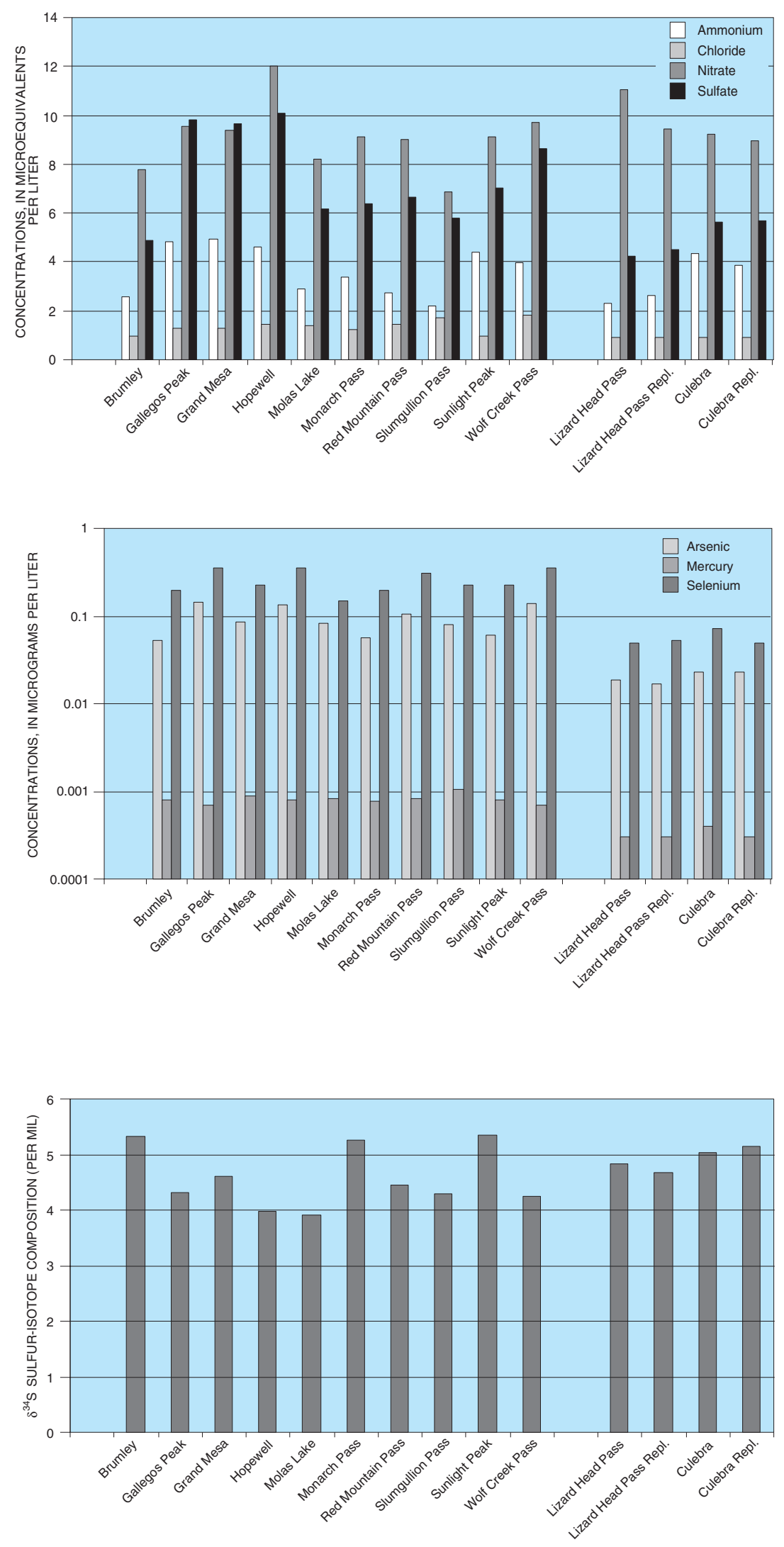

Figure 2. Selected major-ion concentrations at snow-sampling sites. Average concentrations for 1993-99 are shown for sites Brumley through Wolf Creek Snow Pass for comparison to February 2000 sampling at Lizard Head Pass and Culebra sites.

Figure 3. Selected trace-element concentrations at snow-sampling sites. Average concentrations for 1993-99 are shown for sites Brumley through Wolf Creek Pass for comparison to February 2000 sampling at Lizard Head Pass and Culebra sites.

Figure 4. $\delta^{34} \mathrm{~S}$ sulfur-isotope compositions at snow-sampling sites. Average values for 1993-99 are shown for sites Brumley through Wolf Creek Pass for comparison to February 2000 sampling at Lizard Head Pass and Culebra sites. 
average snowpack. Because of the utility of this tracer, continued analysis of geographic patterns of emissions sources by using sulfur-isotope ratios should be a priority.

The range of sulfur-isotope ratios in snow at the two sites sampled in February 2000 (4.7 to 5.1 per mil, table 1 and fig. 4) are within the average range (3.9 to 5.3 per mil) at nearby sites, which indicates sulfate in atmospheric deposition throughout the study area was derived from similar sources. In contrast, these ratios were distinctly lighter than ratios of sulfur isotopes in northwestern Colorado (Ingersoll, 1995; Mast and others, in press) where ratios of 6 to 8 per mil consistently have been observed in snowpacks during 1993-99.

Coal analyses listed in table 3 provide a limited comparison of the amounts of sulfur and mercury present in solid coal samples used as fuel for electricity generation at the three power plants in the Four Corners area. The results for sulfur and mercury content from individual power plants compare favorably with those determined independently at the USGS laboratory in Boulder, Colorado. Additional analyses by the USGS for arsenic and selenium are provided for comparison to snowpack chemistry.

\section{SUMMARY AND CONCLUSIONS}

The chemistry of snowfall into the two watersheds surrounding McPhee and Sanchez reservoirs was analyzed in support of separate investigations of the water quality of the two reservoirs. Comparisons were made between the snowpack chemistry from two high-elevation sampling sites in southern Colorado, generally downwind of the Four Corners area, to the 7-year average chemistry at 10 other snow-sampling sites in southern Colorado and northern New Mexico. Although concentrations of ammonium and nitrate in snow were fairly typical compared to averages established at nearby sites, chloride and sulfate concentrations were below the 1993-99 averages, while arsenic, mercury, and selenium in snow were much below the 1993-99 averages. The below-average snowpacks for the 1999-2000 season may have complicated efforts to collect representative concentrations of chemical constituents of interest. Yet, very similar sulfur-isotope ratios (that are not a function of precipitation amounts) at the sites sampled during February 2000 and in 1993-99 averages for snowpacks at the nearby sites indicate that the Lizard Head Pass and Culebra sampling sites near McPhee and Sanchez Reservoirs were affected by similar sources of emissions as in nearby areas of Colorado and New Mexico. As chemistry data for 1999-2000 snowpacks at other sites in the study area become available, analyses of geographic patterns of chemical concentrations of ammonium, chloride, nitrate, sulfate, arsenic, mercury, and selenium will be possible to determine how the limited snowfall season may have affected chemical concentrations in snowpacks.

Monitoring of annual snowpack chemistry in the study area should be continued for a better understanding of the effects of above- or below-average precipitation years on deposition chemistry. Continued analysis of geographic patterns of emissions sources by using sulfur isotope ratios should be a priority because of the usefulness of the tracer regardless of chemical concentrations or precipitation amounts.

Results from analyses of solid coal samples used as fuels in power plants in the Four Corners area by separate, independent laboratories are provided as an initial baseline for general comparisons of coal chemistry to snowpack chemistry. Mercury and sulfur contents agree favorably between laboratories, and arsenic and selenium were present at detectable levels in coal samples.

Table 3. Selected chemical concentrations in coal used for power production during winter 1999-2000 near Four Corners area

$[\mu \mathrm{g} / \mathrm{g}$, micrograms per gram; Wt. \%, weight percent]

\begin{tabular}{|c|c|c|c|c|c|c|}
\hline \multirow[b]{2}{*}{$\begin{array}{l}\text { Power plant } \\
\text { name }\end{array}$} & \multicolumn{2}{|c|}{ Power Plant Analyses } & \multicolumn{4}{|c|}{ USGS Analyses } \\
\hline & $\begin{array}{c}\text { Mercury } \\
\mu \mathrm{g} / \mathrm{g}\end{array}$ & $\begin{array}{l}\text { Sulfur } \\
\text { Wt. } \%\end{array}$ & $\begin{array}{c}\text { Arsenic } \\
\mu \mathbf{g} / \mathbf{g}\end{array}$ & $\begin{array}{c}\text { Mercury } \\
\mu \mathbf{g} / \mathbf{g}\end{array}$ & $\begin{array}{l}\text { Selenium } \\
\mu \mathbf{g} / \mathbf{g}\end{array}$ & $\begin{array}{l}\text { Sulfur } \\
\text { Wt.\% }\end{array}$ \\
\hline Four Corners & 0.09 & 0.84 & 2.2 & 0.09 & 1.6 & 0.83 \\
\hline Navajo & 0.03 & 0.61 & 1.7 & 0.04 & 1.4 & 0.53 \\
\hline San Juan & 0.08 & 0.87 & 2.3 & 0.08 & 1.7 & 0.83 \\
\hline
\end{tabular}




\section{REFERENCES CITED}

Antweiler, R.C., Patton, C.J., and Taylor, H.E., 1993, Automated, colorimetric methods for the determination of nitrate plus nitrite, nitrite, ammonium, and orthophosphate ions in natural water samples: U.S. Geological Survey Open-File Report 93-638, 23 p.

Brinton, T.I., Antweiler, R.C., and Taylor, H.E., 1996, Method for the determination of dissolved chloride, nitrate, and sulfate in natural waters using ion chromatography: U.S. Geological Survey Open-File Report 95-426A, $16 \mathrm{p}$.

Campbell, D.H., Turk, J.T., and Spahr, N.E., 1991, Response of Ned Wilson Lake Watershed, Colorado, to changes in atmospheric deposition of sulfate: Water Resources Research, v. 27, p. 2047-2060.

Campbell, D.H., Clow, D.W., Ingersoll, G.P., Mast, M.A., Spahr, N.E., and Turk, J.T., 1995, Processes controlling the chemistry of two snowmelt-dominated streams in the Rocky Mountains: Water Resources Research, v. 31, p. 2811-2821.

Cogbill, C. V., and Likens, G.E., 1974, Acid precipitation in the northeastern United States: Water Resources Research, v. 10, p. 1133-1137.

Corn, P. S., Stolzenburg, W., and Bury, R. B., 1989, Acid Precipitation Studies in Colorado and Wyoming: Interim Report of Surveys of Montane Amphibians and Water Chemistry, U.S. Fish and Wildlife Service, National Ecology Research Center, Ecology and Systematics Section, Fort Collins, CO, 56 p.

Denning, A.S., Baron, J., Mast, M. A., and Arthur, M., 1991, Hydrologic pathways and chemical composition of runoff during snowmelt in Loch Vale watershed, Rocky Mountain National Park: Water, Air and Soil Pollution, v. 59, p. 107-123.

Faure, G., 1986, Principles of isotope geology (2d ed): New York, John Wiley, $589 \mathrm{p}$.

Garbarino, J.R., and Taylor, H.E., 1979, An inductively coupled plasma atomic-emission spectrometric method for routine water quality testing: Applied Spectroscopy, v. 33, p. 220-225.

Garbarino, J.R., and Taylor, H.E., 1995, Inductively coupled plasma-mass spectrometric method for the determination of dissolved trace elements in natural water: U.S. Geological Survey Open-File Report 94-358, 88 p.

Gillespie, M.A., 1991, Colorado annual data summary, water year 1991, USDA-National Resources Conservation Service, 655 Parfet St., Rm E200C, Lakewood, CO 80215.

Gillespie, M.A., 2000, Colorado basin outlook report March 1, 2000, USDA - National Resources Conservation Service, 655 Parfet St., Rm E200C, Lakewood, CO 80215.
Ingersoll, G.P., 1995, Maximum-accumulation snowpack chemistry at selected sites in northwestern Colorado during spring 1994: U.S. Geological Survey Open-File Report 95-139, 14 p.

Ingersoll, G.P., 1999, Effects of snowmobile use on snowpack chemistry in Yellowstone National Park, 1998: U.S. Geological Survey Water Resources Investigations Report 99-4148, 23 p.

Lewis, W.M., Jr., Grant, M.C., and Saunders, J.F. III., 1984, Chemical patterns of bulk atmospheric deposition in the State of Colorado: Water Resources Research, v. 20, p. 1691-1704.

Mast, A.M., Turk, J.T., Ingersoll, G.P., Clow, D.W., and Kester, C., in press, Use of stable sulfur isotopes to identify sources of sulfate in Rocky Mountain snowpacks.

National Acid Precipitation Assessment Program, 1998, Biennial report to Congress: an integrated assessment, National Acid Precipitation Assessment Program, Silver Spring, Maryland, $118 \mathrm{p}$.

National Atmospheric Deposition Program, 2000, National Atmospheric Deposition Program 1998 wet deposition: NADP Data Report 2000-01, Illinois State Water Survey, Champaign, IL., 16 p.

Turk, J.T., and Campbell, D.H., 1987, Estimates of acidification of lakes in the Mt. Zirkel Wilderness Area, Colorado: Water Resources Research, v. 23, p. $1757-1766$.

Turk, J.T., Campbell, D.H., Ingersoll, G.P., and Clow, D.W., 1992, Initial findings of synoptic snowpack sampling in the Colorado Rocky Mountains: U.S. Geological Survey Open-File Report 92-645, 6 p.

Turk, J.T., and Campbell, D.H., 1997, Are aquatic resources of the Mount Zirkel Wilderness Area in Colorado affected by acid deposition and what will emissions reduction at the local power plants do?: U.S. Geological Survey Fact Sheet FS-043-97, 4 p.

U.S. Environmental Protection Agency, 2000a, Airsdata Website: http://www.epa.gov/airsdata/mapview.htm. Accessed July 6, 2000.

U.S. Environmental Protection Agency, 2000b, Electric utility steam generating units hazardous air pollutant emission study, Unified Air Toxics Website: http://www.epa.gov/ttn/uatw/combust/utiltox lutoxpg.html\#WEB. Accessed July 6, 2000.

Williams, M.W., Baron, J.S., Caine, N., Sommerfeld, R.A., and Sanford, R. Jr., 1996, Nitrogen saturation in the Rocky Mountains: Environmental Science and Technology, v. 30, p. 640-646.

Williams, M.W., Bardsley, T., and Rikkers, M., 1998, Overestimation of snow depth and inorganic nitrogen wetfall using NADP data, Niwot Ridge, Colorado: Atmospheric Environment, v. 32, p. 3827-3833. 